\title{
Swadeshi swag in textile business
}

\author{
S. Aishwariya
}

Received: 13.08.2019; Accepted: 30.11.2019

See end of the paper for authors' affiliations S. Aishwariya Department of Textiles and Clothing, Avinashilingam Institute for Home Science and Higher Education for Women, Coimbatore (T.N.) India Email : aishu55@gmail.com
KEY WORDS: Swadeshi swag, Textile business

- HOW TO CITE THIS PAPER : Aishwariya, S. (2019). Swadeshi swag in textile business. Asian J. Home Sci., 14 (2) : 473-476, DOI: 10.15740/HAS/AJHS/14.2/473-476. Copyright@ 2019: Hind Agri-Horticultural Society. 